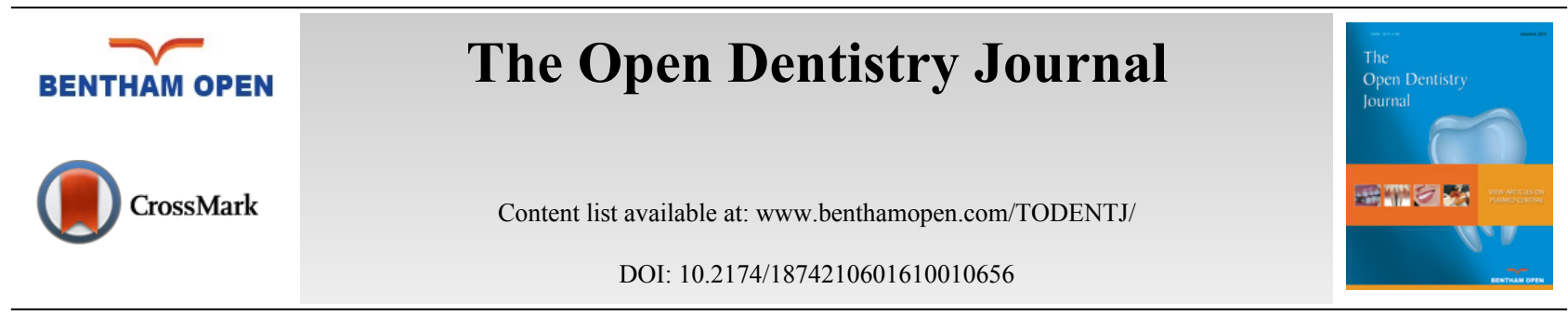

RESEARCH ARTICLE

\title{
Patient's Satisfaction with Removable Partial Dentures: A Retrospective Case Series
}

Kujtim Sh. Shala", Linda J. Dula, Teuta Pustina-Krasniqi, Teuta Bicaj, Enis F. Ahmedi, Zana LilaKrasniqi and Arlinda Tmava-Dragusha

Department of Prosthetic Dentistry, Faculty of Medicine, School of Dentistry, Prishtina, Kosovo

Received: February 26, 2016

Revised: October 09, 2016

Accepted: October 15, 2016

\section{Abstract:}

This retrospective clinical study aimed to assess patient's satisfaction with removable partial dentures (RPDs), as retention, chewing ability, aesthetics during the observation period.

\section{Material and Methods:}

A total of 63 patients with RPDs, participated in this study. The following data was collected: Kennedy classification, denture design, denture support, satisfaction and success of RPD.

\section{Result:}

The results showed that $73.6 \%$ of patients were wearing RPD for the first time and were finally satisfied. According to the denture support of RPDs, clasp-retained quadrangular RPDs were 100\% effective, followed by triangular dental support $81 \%$ and linear dental support $47.7 \%$.

Comparison of RPDs with attachment with RPDs with claps assessed through Fisher exact test, confirmed statistically significant difference $(\mathrm{P}=0.008)$, despite retention; however, chewing ability and aesthetics showed no statistically significant difference with $\mathrm{X}^{2 \text { test }}$ on patient's satisfaction with RPD with or without attachment.

\section{Conclusion:}

Patients often would prefer not showing the anterior buccal clasps of RPD, therefore are generally satisfied more with RPD with attachment based on level of retention, chewing ability and aesthetics.

Keywords: Removable partial denture, Retention, Chewing ability, Aesthetics, Buccal clasps.

\section{INTRODUCTION}

Removable partial denture (RPD) remains the primary form of dental restoration in Kosovo's population, since it is one of the cheapest treatment options for patients who are unable to afford treatment with implants either due to anatomical or economic reasons $[1,2]$. This relates to the fact that Kosovo is a country which is underdeveloped and has low levels of income compared to people in the developed countries.

According to De Van's, the main purpose of partial denture therapy should always be "conservation of that which remains, not the meticulous replacement of what has been lost". Therefore the RPDs are an acceptable form of treatment that provides an increased spectrum of restorative options: maintaining or improving phonetics, establishing or increasing masticatory efficiency, stabilizing dental relationships and developing the required aesthetics [3]. RPDs

\footnotetext{
* Address correspondence to this author at the Department of Prosthetic Dentistry, Faculty of Medicine, School of Dentistry, Prishtina, Kosovo, Prishtina, Albania; Tel: +37744126354; Fax:+38138512474; E-mails: kujtim.shala@uni-pr.edu,drlindadula@gmail.com
} 
can be retained and stabilized with clasps and variety of attachment components which have the ability to resist denture dislodgement [4]. RPD retentive clasp arms must be capable of flexing and returning to original forms; [5] on the other hand the attachment-retained cast partial dentures facilitate both aesthetic and functional replacement of missing teeth and both retentive elements should satisfactorily retain RPDs [6].

Satisfaction with RPD depends on individuality of patients, attitude towards RPD, previous RPD experience, encouragement for denture and design and fabrication procedure for RPD [7 - 9]. Retention, chewing ability, aesthetics, seem to be the most important factors for RPD acceptance [10,11]. Patient's dissatisfaction with removable partial denture also depends on some of reasons such as risk to local damage of the remaining teeth, for e.g. caries, periodontal disease, plaque accumulation, oral candidiasis, denture stomatitis, etc. [12 - 16]. Also, RPD is an aesthetic problem for most people and can affect the appearance and interpersonal communication $[17,18]$.

The aim: This retrospective clinical study aimed to assess patient's satisfaction with removable partial dentures (RPDs), for retention, chewing ability, aesthetics during the observation period.

\section{MATERIALS AND METHODOLOGY}

A sample of 63 patients, aged from 40 to 64 years with RPD has participated in this study. The research was approved by the Institutional Ethic Committee of the University Dentistry Clinical Center of Kosovo. Informed consent was obtained from each subject participating in this study.

Inclusion criteria were patients with partially RPDs wearers, no parafunctional habits, no known disabilities that may have an effect on RPD maintenances, opposing natural teeth or opposing RPDs wearers. Ninety-one RPDs were examined, and each prosthesis was considered a statistically independent case, since some patients had RPD in both jaws, there were a total of 91 RPDs. In this study, 73.6\% of patients had taken RPD for the first time and were satisfied with it. Also patients with second RPDs and third RPDs were satisfied with the new RPDs. The subjects were selected at the Department of Prosthodontics, Dental School, Faculty of Medicine, and University of Prishtina in Kosovo. Specialist of prosthodontics assessed Kennedy classification, denture design, denture support, satisfaction and success of RPD.

The RPD classifications were proposed by Dr. Edward Kennedy in 1925 [19]. The main factor in the classification system, according to Kennedy, is its ability to demonstrate the location of denture support in relation to the space without teeth. In the present study the most common class was found to be the Kennedy Class I with 34 patients. Kennedy's modification with one further edentulous area IIA had 12 patients and IA had 11 patients. In Kennedy Class II there were 10 patients, Kennedy's modification with two further edentulous areas IIB there were 4 patients and IB there were 3 patients, followed by Class IV where there were 3 patients and IVA there were 2 patients and the least prevalent was Class IIIA and IIIB with 1 patient. On the basis of the principles, concepts and practice, classification should allow immediate visualization of large type connector and its relation with the remaining teeth and soft tissue [20].

Denture design for each subject should be based on the biomechanics factors, giving priority to principles such as retention, stability and support. There were seventy-five RPDs with clasp-retained extra coronal direct and indirect retainers Ney claps and sixteen RPDs with extracoronal precision attachment with Ceka, is still a common practice for patients. The framework casts were made by cobalt-chrome-molbiden alloys (Co-Cr-Mo).

Denture support of the RPDs was classified point and linear, triangular and quadrangular design according to Steffel in 1962 [21].

Satisfaction and success of RPDs was derived by questions; subjects were asked about their general satisfactions with retention, chewing ability, aesthetics, using scale that ranged from 4-excellent to 1-bad, as is common in our society and in Kosovo's educational system. The level of RPDs acceptance was classified as excellent, good, medium and bad. Excellent indicates the absence of any difficulty on chewing ability, retention and aesthetics and bad indicate more impairment on retention, chewing ability and aesthetics. Success of RPD was graded in three categories based on its function/condition: complete success, partial success and failure.

The survey data were organized and analyzed using (SPSS) 19 for Windows (SPSS Inc., Chicago, Illinoiss, USA) and MS Excel (Microsoft Office, Windows 2007, USA). Differences were considered significant when $P<0.05$. 


\section{RESULTS}

The basic descriptive statistics showed comparison of gender and age Table 1. RPD denture support and distribution of denture arch and Kennedy Classification are presented in Tables $\mathbf{2}$ and $\mathbf{3}$ respectively.

Table 1. Comparison of gender and age.

\begin{tabular}{|c|c|c|c|c|c|c|c|}
\hline \multirow{3}{*}{$\begin{array}{l}\text { Age group } \\
\text { (year) }\end{array}$} & & \multicolumn{4}{|c|}{ Gender } & & \\
\hline & & \multicolumn{2}{|c|}{$\mathbf{F}$} & \multicolumn{2}{|c|}{ M } & \multicolumn{2}{|c|}{ Total } \\
\hline & & $\mathbf{N}$ & $\%$ & $\mathbf{N}$ & $\%$ & $\mathbf{N}$ & $\%$ \\
\hline \multicolumn{2}{|l|}{$<40$} & 1 & 3.6 & - & - & 1 & 1.6 \\
\hline \multicolumn{2}{|l|}{$40-64$} & 19 & 67.9 & 18 & 50.0 & 37 & 57.8 \\
\hline \multicolumn{2}{|l|}{$65+$} & 7 & 28.6 & 18 & 50.0 & 26 & 40.6 \\
\hline \multirow{2}{*}{ Gjithsej } & $\mathbf{N}$ & 27 & 100.0 & 36 & 100.0 & 63 & 100.0 \\
\hline & $\%$ & 43.8 & - & 56.3 & - & 100.0 & - \\
\hline \multicolumn{2}{|c|}{ Mean \pm SD } & \multicolumn{2}{|c|}{$57.2 \pm 10.3$} & \multicolumn{2}{|c|}{$64.5 \pm 7.7$} & \multicolumn{2}{|c|}{$61.4 \pm 9.6$} \\
\hline \multicolumn{2}{|l|}{ Rank } & \multicolumn{2}{|c|}{$34-75$} & \multicolumn{2}{|c|}{$46-79$} & \multicolumn{2}{|c|}{$34-79$} \\
\hline
\end{tabular}

Table 2. RPD Denture support according to Steffel and distribution of denture arch $(n=91)$.

\begin{tabular}{|c|c|c|}
\hline & $\mathbf{N}$ & $\%$ \\
\hline \multicolumn{3}{|l|}{ Support } \\
\hline Quadrangular & 6 & 6.5 \\
\hline Triangular & 21 & 22.8 \\
\hline Linear & 44 & 47.8 \\
\hline Over one point & 4 & 4.3 \\
\hline Total RPD with clasp & 75 & 81.5 \\
\hline RPD with attachments & 16 & 17.4 \\
\hline \multicolumn{3}{|l|}{ Arch } \\
\hline Maxilla & 41 & 44.6 \\
\hline Mandible & 50 & 55.4 \\
\hline
\end{tabular}

Table 3. Distribution of kennedy classification.

\begin{tabular}{|l|c|c|}
\hline \multirow{2}{*}{$\begin{array}{l}\text { Kennedy } \\
\text { Classification }\end{array}$} & $\mathbf{2}$ & \multicolumn{1}{|c|}{ Total } \\
\cline { 2 - 3 } I & 34 & 37.4 \\
\hline I A & 11 & 12.1 \\
\hline I B & 3 & 3.3 \\
\hline II & 10 & 11.0 \\
\hline II A & 12 & 13.2 \\
\hline II B & 4 & 4.4 \\
\hline IIIA & 1 & 1.1 \\
\hline III B & 1 & 1.1 \\
\hline IV & 3 & 3.3 \\
\hline IV A & 2 & 2.2 \\
\hline Subtotal & 10 & 11.0 \\
\hline Total & $\mathbf{9 1}$ & $\mathbf{1 0 0 . 0}$ \\
\hline
\end{tabular}

The results showed that $73.6 \%$ of patients have taken RPDs for the first time and were finally satisfied with it. Also, $14.3 \%$ patients with second RPDs and $12.1 \%$ with third RPDs have opted for RPDs again (Table 4).

Tabela 4. According to pair of RPD's wearing.

\begin{tabular}{|l|c|c|c|c|c|c|}
\hline \multirow{2}{*}{ RPD was } & \multicolumn{2}{|c|}{ RPDs } & \multicolumn{2}{|c|}{$\begin{array}{c}\text { RPDs } \\
\text { with atachment }\end{array}$} & \multicolumn{2}{c|}{ Total } \\
\cline { 2 - 8 } & $\mathbf{N}$ & $\mathbf{\%}$ & $\mathbf{N}$ & $\mathbf{\%}$ & $\mathbf{N}$ & $\mathbf{\%}$ \\
\hline The first RPDs & 55 & 73.3 & 12 & 75.0 & 67 & 73.6 \\
\hline
\end{tabular}


(Table $\square$ ) contd......

\begin{tabular}{|c|c|c|c|c|c|c|}
\hline \multirow[b]{2}{*}{ RPD was } & \multicolumn{2}{|c|}{ RPDs } & \multicolumn{2}{|c|}{$\begin{array}{c}\text { RPDs } \\
\text { with atachment }\end{array}$} & \multicolumn{2}{|c|}{ Total } \\
\hline & $\mathbf{N}$ & $\%$ & $\mathbf{N}$ & $\%$ & $\mathbf{N}$ & $\%$ \\
\hline The second RPDs & 12 & 16.0 & 1 & 6.3 & 13 & 14.3 \\
\hline The third RPDs & 8 & 10.7 & 3 & 18.8 & 11 & 12.1 \\
\hline Total & 75 & 100.0 & 16 & 100.0 & 91 & 100.0 \\
\hline
\end{tabular}

According to the denture support of RPDs, patients with RPDs with clasp-retained quadrangular denture support have effect on the success rate. However, the Spearman's rank correlation confirmed no statistically significant difference between success of dental support of RPDs $(r=0.104, P=0.325)$ (Table 5). Otherwise the RPDs with attachment retained were almost Kennedy Class I, linear dental support.

Table 5. Patient's success of RPD's with clasp-retained according to denture support.

\begin{tabular}{|c|c|c|c|c|c|c|c|c|}
\hline \multirow{2}{*}{$\begin{array}{l}\text { Patient's } \\
\text { success }\end{array}$} & \multicolumn{2}{|c|}{ Quadrangular } & \multicolumn{2}{|c|}{ Triangular } & \multicolumn{2}{|c|}{ Linear } & \multicolumn{2}{|c|}{ One point } \\
\hline & $\mathbf{N}$ & $\%$ & $\mathbf{N}$ & $\%$ & $\mathbf{N}$ & $\%$ & $\mathbf{N}$ & $\%$ \\
\hline Full & 6 & 100.0 & 17 & 81.0 & 21 & 47.7 & - & - \\
\hline Partial & - & - & 4 & 19.0 & 19 & 43.2 & 4 & 100.0 \\
\hline Failure & - & - & - & - & 4 & 9.1 & - & - \\
\hline \multirow[t]{2}{*}{ Total } & 6 & 100.0 & 21 & 100.0 & 44 & 100.0 & 4 & 100.0 \\
\hline & \multicolumn{8}{|c|}{$\mathrm{r}=0.104, \mathrm{P}=0.325$} \\
\hline
\end{tabular}

After insertion the great majority of patients were very satisfied with the RPDs. According to the denture design of RPDs with Fisher exact test we confirmed statistically significant difference $(\mathrm{P}=0.008)$ of patient's success of RPDs with attachment compared to RPDs with claps (Table 6).

Table 6. Patient's success of RPDs

\begin{tabular}{|c|c|c|c|c|}
\hline \multirow{2}{*}{$\begin{array}{l}\text { Patient's } \\
\text { success }\end{array}$} & \multicolumn{2}{|c|}{ RPDs } & \multicolumn{2}{|c|}{$\begin{array}{c}\text { RPDs } \\
\text { with atachment }\end{array}$} \\
\hline & $\mathbf{N}$ & $\%$ & $\mathbf{N}$ & $\%$ \\
\hline Full & 44 & 58.7 & 15 & 93.8 \\
\hline Partial & 27 & 36.0 & 1 & 6.3 \\
\hline \begin{tabular}{|l|} 
Failure \\
\end{tabular} & 4 & 5.3 & - & - \\
\hline Total & 75 & 100.0 & 16 & 100.0 \\
\hline Fisher test & \multicolumn{4}{|c|}{$P=0.008$} \\
\hline
\end{tabular}

Retention, chewing ability, aesthetics had no statistically significant difference with $\mathrm{X}^{2 \text { test }}$ of patient's satisfaction of RPD with or without attachment (Tables 7-9). Because of the small number of patients with RPD with attachment, the difference has not been significant and the results must be judged carefully.

Table 7. Patient's satisfaction with denture retention according to design of RPDs.

\begin{tabular}{|c|c|c|c|c|c|c|}
\hline \multirow[b]{2}{*}{ Retention } & \multicolumn{2}{|c|}{ RPDs } & \multicolumn{2}{|c|}{$\begin{array}{c}\text { RPDs } \\
\text { with atachment }\end{array}$} & \multicolumn{2}{|c|}{ Total } \\
\hline & $\mathbf{N}$ & $\%$ & $\mathbf{N}$ & $\%$ & $\mathbf{N}$ & $\%$ \\
\hline Excellent & 20 & 37.7 & 5 & 50.0 & 25 & 39.7 \\
\hline Good & 23 & 43.4 & 5 & 50.0 & 28 & 44.4 \\
\hline Medium & 6 & 11.3 & - & - & 6 & 9.5 \\
\hline $\mathrm{Bad}$ & 4 & 7.5 & - & - & 4 & 6.3 \\
\hline \multirow[t]{2}{*}{ Total } & 53 & 100.0 & 10 & 100.0 & 63 & 100.0 \\
\hline & \multicolumn{4}{|c|}{$\mathrm{X}^{2}=2.28, P=0.319$} & & \\
\hline
\end{tabular}


Table 8. Patient's satisfaction with chewing ability according to denture design of RPDs.

\begin{tabular}{|c|c|c|c|c|c|c|}
\hline \multirow{2}{*}{$\begin{array}{l}\text { Chewing } \\
\text { ability }\end{array}$} & \multicolumn{2}{|c|}{ RPDs } & \multicolumn{2}{|c|}{$\begin{array}{c}\text { RPDs } \\
\text { with atachment }\end{array}$} & \multicolumn{2}{|c|}{ Total } \\
\hline & $\mathbf{N}$ & $\%$ & $\mathbf{N}$ & $\%$ & $\mathbf{N}$ & $\%$ \\
\hline Excellent & 14 & 26.4 & 2 & 20.0 & 16 & 25.4 \\
\hline Good & 28 & 52.8 & 7 & 70.0 & 35 & 55.6 \\
\hline Medium & 9 & 17.0 & 1 & 10.0 & 10 & 15.9 \\
\hline $\mathrm{Bad}$ & 2 & 3.8 & - & - & 2 & 3.2 \\
\hline \multirow[t]{2}{*}{ Total } & 53 & 100.0 & 10 & 100.0 & 63 & 100.0 \\
\hline & \multicolumn{4}{|c|}{$\mathrm{X}^{2}=1.09, P=0.579$} & & \\
\hline
\end{tabular}

Table 9. Patient's satisfaction with aesthetics according to denture design of RPDs.

\begin{tabular}{|c|c|c|c|c|c|c|}
\hline \multirow[b]{2}{*}{ Aesthetics } & \multicolumn{2}{|c|}{ RPDs } & \multicolumn{2}{|c|}{$\begin{array}{c}\text { RPDs } \\
\text { with atachment }\end{array}$} & \multicolumn{2}{|c|}{ Total } \\
\hline & $\mathbf{N}$ & $\%$ & $\mathbf{N}$ & $\%$ & $\mathbf{N}$ & $\%$ \\
\hline Exellent & 21 & 39.6 & 5 & 50.0 & 26 & 41.3 \\
\hline Good & 30 & 56.6 & 4 & 40.0 & 34 & 54.0 \\
\hline Medium & 2 & 3.8 & 1 & 10.0 & 3 & 4.8 \\
\hline \multirow[t]{2}{*}{ Total } & 53 & 100.0 & 10 & 100.0 & 63 & 100.0 \\
\hline & \multicolumn{4}{|c|}{$\mathrm{X}^{2}=0.06, P=0.794$} & & \\
\hline
\end{tabular}

\section{DISCUSSION}

Rehabilitation of patients with removable partial dentures (RPD) is a continuous process and requires attention to the specific needs of the patients, especially in Kennedy class I and II. Patients should be physically and psychologically prepared to accept a treatment with RPDs [22, 23]. The most common class of partial edentulous in the present study were Kennedy Class I followed by Class II, Class IV and least prevalent was Class III. In support to our findings, Anderson et al. [24] and Deo K. [25] showed similar result. Despite our survey, Bharathi M et al. [26] concluded that Kennedy Class III is more frequent type followed by Class I, Class II and Class IV.

The satisfaction of patients is also influenced by denture support. Patients with RPDs with clasp-retained quadrangular denture support have full $100 \%$ effect on the success rate, followed by triangular dental support $81 \%$ and linear dental support with 47.7\%. Based on Kennedy classification, patients with Class III and IIA were more satisfied with RPDs.

Patients with previous RPDs experience would be expected to be more satisfied [27]. However, in this study, 73.6\% of patients have taken RPDs for the first time and for that reason experience did not show significant association with RPD use. Past experience alone may not be a highly predictive indicator of future satisfaction [28].

Based on denture design of RPD we confirmed statistically significant difference $(\mathrm{P}=0.008)$ of patient's success of RPDs with attachment compared with RPDs with claps which agree with the results of Owall B [29]. The results of this study, considering patient's satisfaction were better when we used combination with fixed partial dentures retained with attachment (93.8\%) compared with RPDs retained with claps (58.7\%). Similar results reported that the presence of anterior teeth in an RPD could influence patient's satisfaction [30].

According to the results of this study retention, chewing ability, aesthetics proved no statistically significant difference with $\mathrm{X}^{2 \text { test }}$ of patient's satisfaction based on denture design of RPD. Most of the patients (50.0\%) rated the retention and the aesthetics with their RPDs retained with attachment as "excellent" compared with RPDs retained with claps (37.7\%). Patient's satisfaction with chewing ability according to denture design of RPD was "good" in (70.0\%) of patients with their RPDs retained with attachment compared with RPDs retained with claps (52.8\%). This finding is in agreement with the results of Cosme DC et al., which stated that the great majority of patients were very satisfied with RPDs [31].

It has been suggested that RPDs use does not necessarily improve patient satisfaction unless it increases occlusal units [32]. Patients with at least 25 intact teeth are more satisfied with any type of prosthesis than patients with 1 to 24 intact teeth [33]. Other studies have shown that improved aesthetics is more important inspiration for patients to wear RPDs than function [34, 35]. According to Yen YY et al., denture satisfaction is useful for assessing the effect of 
denture treatment on the OHRQoL of elderly individuals wearing RPD [36]. In addition loss of retention of the dentures may have impaired the patients' ability to chew causing dissatisfaction [37]. Treatment with removable partial dentures is an ongoing process and requires careful attention to the specific needs of the patient.

\section{CONCLUSION}

Regarding quality of dentures, patients are generally satisfied more with RPD with attachment based on level of retention, chewing ability and aesthetics, because they prefer not showing the anterior buccal clasps of RPD. They showed positive attitude toward removable partial denture, even nowadays some patients are unable to afford complicated treatments with implants, therefore RPD can be considered as an economical treatment choice for elderly patients and totally fulfill their expectations. If patient expectations are realistic, then acceptance of the RPDs could be improved; potentially satisfaction and success rates.

\section{CONFLICT OF INTEREST}

The authors confirm that this article content has no conflict of interest.

\section{ACKNOWLEDGEMENTS}

$\mathrm{KSH}$ and LD collected all the data from the patients, participated in the writing of the manuscript and in the statistical analysis. TPK, TB, EA ZLK, and ATD were principal investigators and participated in all phases of the manuscript and advised how to conduct the statistical analysis. KSH has been the supervisor of the project. All authors read and approved the final manuscript and participated in the bibliography review.

The authors acknowledge all the patients of the University Dentistry Clinical Center, Pristina, Kosova that have facilitated in this study.

\section{REFERENCES}

[1] Nassani MZ, Tarakji B, Baroudi K, Sakka S. Reappraisal of the removable partial denture as a treatment option for the shortened dental arch. Eur J Dent 2013; 7(2): 251-6.

[http://dx.doi.org/10.4103/1305-7456.110199] [PMID: 24883037]

[2] Yang Y, Zhang H, Chai Z, Chen J, Zhang S. Multiple logistic regression analysis of risk factors associated with denture plaque and staining in Chinese removable denture wearers over 40 years old in Xiana cross-sectional study. PLoS One 2014; 9(2): e87749. [http://dx.doi.org/10.1371/journal.pone.0087749] [PMID: 24498369]

[3] Phoenix Rodney D, Cagna David R, DeFreest Charles F. Stewarts's Clinical removable partial Prosthodontics, $4^{\text {th }}$ ed. Warsaw: Quintessence Publishing Co., Inc. 2008

[4] Bakers JL, Goodkind RJ. Precision Attachment Removable Partial Dentures, San Mateo, California, USA: Mosby. 1981.

[5] Ramamoorthi M, Al Khuraif AA. A Comparative evaluation of fatigue behavior of removable partial denture alloys with and without heat treatment. Int J Dental Clin 2011; 3(1): 14-7.

[6] Burns DR, Ward JE. Review of attachments for removable partial denture design: 1. Classification and selection. Int J Prosthodont 1990; 3(1): 98-102. [PMID: 2196898]

[7] Frank RP, Brudvik JS, Leroux B, Milgrom P, Hawkins N. Relationship between the standards of removable partial denture construction, clinical acceptability, and patient satisfaction. J Prosthet Dent 2000; 83(5): 521-7. [http://dx.doi.org/10.1016/S0022-3913(00)70008-4] [PMID: 10793382]

[8] Knezović Zlatarić D, Celebić A, Valentić-Peruzović M, Jerolimov V, Pandurić J. A survey of treatment outcomes with removable partial dentures. J Oral Rehabil 2003; 30(8): 847-54. [http://dx.doi.org/10.1046/j.1365-2842.2003.01039.x] [PMID: 12880410]

[9] Chen J, Ahmad R, Suenaga H, et al. Shape optimization for additive manufacturing of removable partial denturesA new paradigm for prosthetic CAD/CAM. PLoS One 2015; 10(7): e0132552. [http://dx.doi.org/10.1371/journal.pone.0132552] [PMID: 26161878]

[10] Reifel NM, Rana H, Marcus M. Consumer satisfaction. Adv Dent Res 1997; 11(2): 281-90. [http://dx.doi.org/10.1177/08959374970110021101] [PMID: 9549994]

[11] Hoad-Reddick G, Grant AA. Prosthetic status: the formation of a schedule. J Prosthet Dent 1988; 59(1): 105-10. [http://dx.doi.org/10.1016/0022-3913(88)90118-7] [PMID: 3276871]

[12] Kern M, Wagner B. Periodontal findings in patients 10 years after insertion of removable partial dentures. J Oral Rehabil 2001 ; $28(11)$ : $991-7$. [http://dx.doi.org/10.1046/j.1365-2842.2001.00788.x] [PMID: 11722713] 
[13] Yeung AL, Lo EC, Chow TW, Clark RK. Oral health status of patients 56 years after placement of cobalt-chromium removable partial dentures. J Oral Rehabil 2000; 27(3): 183-9. [http://dx.doi.org/10.1046/j.1365-2842.2000.00512.x] [PMID: 10784329]

[14] Yusof Z, Isa Z. Periodontal status of teeth in contact with denture in removable partial denture wearers. J Oral Rehabil 1994; 21 (1): 77-86. [http://dx.doi.org/10.1111/j.1365-2842.1994.tb01126.x] [PMID: 8133391]

[15] Lalla RV, Patton LL, Dongari-Bagtzoglou A. Oral candidiasis: pathogenesis, clinical presentation, diagnosis and treatment strategies. J Calif Dent Assoc 2013; 41(4): 263-8. [PMID: 23705242]

[16] Milton Rocha Gusmão J, Pereira RP. Treatment protocol for denture stomatitis, prior to anatomical molding. Gerodontology 2013; 30(3): 232-5. [http://dx.doi.org/10.1111/j.1741-2358.2012.00661.x] [PMID: 22506854]

[17] Al-Huraishi H, Moran J, Jagger R, MacDonald E. Evaluation of stain removal and inhibition properties of eight denture cleansers: an in vitro study. Gerodontology 2013; 30(1): 10-7. [http://dx.doi.org/10.1111/j.1741-2358.2011.00522.x] [PMID: 23088443]

[18] Alam M, Jagger R, Vowles R, Moran J. Comparative stain removal properties of four commercially available denture cleaning products: an in vitro study. Int J Dent Hyg 2011; 9(1): 37-42. [http://dx.doi.org/10.1111/j.1601-5037.2009.00432.x] [PMID: 21226849]

[19] McGivney GP, Carr AB. McCracken's removable partial prosthodontics. 10th ed. St. Louis, MO 2000 ; pp. 19-23.

[20] Principles, concepts, and practices in prosthodontics1994. J Prosthet Dent 1995; 73(1): 73-94. [http://dx.doi.org/10.1016/S0022-3913(05)80276-8] [PMID: 7699604]

[21] Steffel VL. Planing removable partial dentures. J Prosthet Dent 1962; 12: 524-35. [http://dx.doi.org/10.1016/0022-3913(62)90135-X]

[22] Dula LJ, Shala KSh, Pustina-Krasniqi T, Bicaj T, Ahmedi EF. The influence of removable partial dentures on the periodontal health of abutment and non-abutment teeth. Eur J Dent 2015; 9(3): 382-6. [http://dx.doi.org/10.4103/1305-7456.163234] [PMID: 26430367]

[23] Pellizzer EP, Ferraço R, Tonella BP, Oliveira BJ, Souza FL, Falcón-Antenucci RM. Influence of ridge type on mandibular distal extension removable partial denture. Acta Odontol Latinoam 2010; 23(1): 68-73. [PMID: 20645647]

[24] Anderson JN, Lammie GA. A clinical survey of partial dentures. Br Dent J 1952; 92: 59-67.

[25] Deo K. Pun Marquette Universit Incidence of Removable Partial Denture Types in Eastern Wisconsin. Master's Thesis 2009.

[26] Bharathi M, Babu KR, Reddy G, Gupta N, Misuriya A, Vinod V. Partial Edentulism based on Kennedys classifcation: an epidemiological study. J Contemp Dent Pract 2014; 15(2): 229-31.

[http://dx.doi.org/10.5005/jp-journals-10024-1520] [PMID: 25095849]

[27] Frank RP, Milgrom P, Leroux BG, Hawkins NR. Treatment outcomes with mandibular removable partial dentures: a population-based study of patient satisfaction. J Prosthet Dent 1998; 80(1): 36-45. [http://dx.doi.org/10.1016/S0022-3913(98)70089-7] [PMID: 9656176]

[28] Akeel RF. Effect of the quality of removable prostheses on patient satisfaction. J Contemp Dent Pract 2009; 10(6): E057-64. [PMID: 20020082]

[29] Owall B. Precision attachment-retained removable partial dentures: Part 2. Long-term study of ball attachments. Int J Prosthodont 1995; 8(1): 21-8.

[PMID: 7710621]

[30] Frank RP, Milgrom P, Leroux BG, Hawkins NR. Treatment outcomes with mandibular removable partial dentures: a population-based study of patient satisfaction. J Prosthet Dent 1998; 80(1): 36-45. [http://dx.doi.org/10.1016/S0022-3913(98)70089-7] [PMID: 9656176]

[31] Cosme DC, Baldisserotto SM, Fernandes EdeL, Rivaldo EG, Rosing CK, Shinkai RS. Functional evaluation of oral rehabilitation with removable partial dentures after five years. J Appl Oral Sci 2006; 14(2): 111-6. [http://dx.doi.org/10.1590/S1678-77572006000200009] [PMID: 19089041]

[32] Van Waas M, Meeuwissen J, Meuwissen R, Käyser A, Kalk W, Van t Hof M. Relationship between wearing a removable partial denture and satisfaction in the elderly. Community Dent Oral Epidemiol 1994; 22(5 Pt 1): 315-8. [http://dx.doi.org/10.1111/j.1600-0528.1994.tb02059.x] [PMID: 7813184]

[33] Jones JA, Orner MB, Spiro A III, Kressin NR. Tooth loss and dentures: patients perspectives. Int Dent J 2003; 53(5)(Suppl.): 327-34. [http://dx.doi.org/10.1111/j.1875-595X.2003.tb00906.x] [PMID: 14562938]

[34] Graham R, Mihaylov S, Jepson N, Allen PF, Bond S. Determining need for a removable partial denture: a qualitative study of factors that influence dentist provision and patient use. Br Dent J 2006; 200(3): 155-8. [http://dx.doi.org/10.1038/sj.bdj.4813193] [PMID: 16474363] 
[35] Koyama S, Sasaki K, Kawata T, Atsumi T, Watanabe M. Multivariate analysis of patient satisfaction factors affecting the usage of removable partial dentures. Int J Prosthodont 2008; 21(6): 499-500. [PMID: 19149065]

[36] Yen YY, Lee HE, Wu YM, et al. Impact of removable dentures on oral health-related quality of life among elderly adults in Taiwan. BMC Oral Health 2015; 5(15): 1.

[37] Bilhan H, Erdogan O, Ergin S, Celik M, Ates G, Geckili O. Complication rates and patient satisfaction with removable dentures. J Adv Prosthodont 2012; 4(2): 109-15.

[http://dx.doi.org/10.4047/jap.2012.4.2.109] [PMID: 22737317]

(C) Shala et al.; Licensee Bentham Open.

This is an open access article licensed under the terms of the Creative Commons Attribution-Non-Commercial 4.0 International Public License (CC BY-NC 4.0) (https://creativecommons.org/licenses/by-nc/4.0/legalcode), which permits unrestricted, non-commercial use, distribution and reproduction in any medium, provided the work is properly cited. 